living expenses in connexion with her proposed visit to the United States to study the uses of electron microscopy and to learn special methods of making ultra-thin sections of plant tissues.

Prof. K. R. Popper, London School of Economics and Political Science : $£ 960$ (about 2,800 dollars) to extend by six months a period of uninterrupted work on problems of social philosophy and the methodology of the social sciences.

Sir Dennis Robertson, professor of political economy in the University of Cambridge: 2,260 dollars to enable him to visit American universities and research centres.

Miss Margaret B. Swann, lecturer in the Depart. ment of Psychological Medicine, University of Glasgow : 2,400 dollars for travel and expenses to visit centres of psychiatric social work in the United States and Canada.

Prof. A. S. T. Thomson, professor of civil and mechanical engineering, Royal Technical College, Glasgow : 1,650 dollars for a visit to sanitary engineering centres in the United States.

Dr. J. Walker, senior lecturer in obstetries, University of Aberdeen : 400 dollars toward travel and living expenses for visits to laboratories of obstetric medicine research in the United States.

\section{USE OF SYNTHETIC DETERGENTS IN GREAT BRITAIN}

$T$ HE increasing use of synthetic detergents has caused many people to ask themselves whether we shall not, sooner or later, have to pay for the benefits we get from them. Housewives, who use them for washing-up and other domestic purposes, have ascribed dermatitis and cracked skins to their use ; some have doubted whether they do not cause corrosion of domestic utensils and plumbing ; industrial users have had similar doubts; and the discharge of industrial and domestic detergents through the sewers has caused serious problems at some sewage works.

The interim report of the Committee on Synthetic Detergents* is therefore of interest to a public that is far wider than those exclusively concerned with the scientific, technical or commercial aspects of detergents. This Committee, appointed in May 1953, is still busily at work ; its general interim conclusion, however, is that there is, as yet, no evidence that users of synthetic detergents need be alarmed about the possible ill-effects of these substances, but that detergents may cause, at some sewage works, a definite nuisance and that they may possibly affect the efficiency of sewage treatment and also the condition of rivers and the purity of water supplies.

Dealing with the possibility that washing products based on synthetic detergents may cause dermatitis of the skin, the Committee says that these washing products may, indeed, thus affect the skins of some people, but that washing-products based on soaps and alkalis may also do this. Medical opinion is apparently variable on this question, but, in spite of the widespread use of synthetic detergents throughout Britain, dermatitis is not more frequent either in households or industries than it was when washing. products based on soaps and alkalis were used.

* Ministry of Housing and Local Government. Interim Report of the Committee on Synthetic Detergents. Pp. 8. (London: H.M.S.o. 1954.) 4d. net.
Many housewives use hand-creams after using synthetic detergents, and they should be taught how much of them to use and not to use them in excessive quantities. There is no evidence that traces of these substances left on crockery or other utensils may get into food or drink and have ill effects. Detergents may remove films of grease or soap from household utensils and plumbing systems and may thus expose them to corrosion, but kitchen utensils and pipes have been exposed for years to corrosive substances containing soda and chlorine and no corrosion problem has arisen. The Committee considers that problems of this kind may be left to the makers of kitchen utensils and furniture.

The most serious problem is the effect of detergents on sewage disposal. The detergents continue to produce foam after they have been discharged into the sewers, and the foam may rise, at some sewage works, to a height of several feet, especially at works where the activated sludge system is used. At some sewage works the foam endangers the operatives and, when it drifts off from the works, it becomes offensive to the neighbourhood; because it may contain particles of unpurified sewage, its suppression is a problem of public health. Although this kind of problem may become more acute, it need not, at present, cause alarm. Further research on methods of suppression of the foam is needed, and it is now going on.

Equally important, or perhaps more so, is the possibility that detergents may add to the difficulty being experienced at some sewage works of keeping the effluents up to the required standard. The Committee is giving special attention to this problem. It is also specially concerned with the discharge of effluents containing detergents into rivers, where they may affect water supplies drawn from the rivers, or the life of animals living in the rivers.

The Committee's experimental work is made more difficult by the fact that large-scale experimental work on sewage and on water supplies is restricted by law and by the need to safeguard the purification of water and sewage. An additional difficulty is the differing chemical composition of the various detergents, none of which is a single chemical substance, so that accurate methods of determining small concentrations of them have still to be devised. The Committee does not, for these reasons, expect to be able to finish its work quickly and gives a warning that all generalizations made about the effects of detergents must be treated with great caution.

\section{PLAY IN DOMESTIC CATTLE IN BRITAIN : AN ANALYSIS OF ITS NATURE}

$T$ HERE is no universally accepted theory of the genesis and goal of play. A. Brownlee, of the Agricultural Research Council Field Station, has recently investigated the manifestations and conditions of occurrence of play in cattle. From his observations he has also carried out both analysis and synthesis in the light of more recent studies of instinctive behaviour and of physiological processes in muscle and the other tissues concerned in play (Brit. Vet. J., 110, No. 2; 1954).

For the most part the observations were carried out intermittently over a period of years on cattle 